\title{
Article \\ Effect of Lane Narrowing Implemented on an Urban Dual Carriageway on Speed Reduction and Acoustic Environment
}

\author{
Alicja Barbara Sołowczuk * (D) and Dominik Kacprzak
}

check for updates

Citation: Sołowczuk, A.B.; Kacprzak, D. Effect of Lane Narrowing Implemented on an Urban Dual Carriageway on Speed Reduction and Acoustic Environment. Buildings 2022, 12, 31. https://doi.org/ 10.3390 /buildings12010031 Academic Editor: Silvia Vilcekova

Received: 10 November 2021 Accepted: 30 December 2021 Published: 31 December 2021

Publisher's Note: MDPI stays neutral with regard to jurisdictional claims in published maps and institutional affiliations.

Copyright: (C) 2021 by the authors. Licensee MDPI, Basel, Switzerland. This article is an open access article distributed under the terms and conditions of the Creative Commons Attribution (CC BY) license (https:// creativecommons.org/licenses/by/ $4.0 /)$.
Department of Roads and Bridges, Faculty of Civil and Environmental Engineering, West Pomeranian University of Technology in Szczecin, 71-311 Szczecin, Poland; dominik.kacprzak@zut.edu.pl

* Correspondence: alicja.solowczuk@zut.edu.pl; Tel.: +48-(091)-449-40-36

Abstract: The on-going growth in the use of motor vehicles leads to a number of traffic safety problems. Therefore, various traffic calming measures are applied to increase traffic safety in built-up areas. Lane narrowing is one of the techniques used to influence the perception of drivers and make them slow down. With this in mind, the authors conducted traffic volume and speed counts before and after installation of the lane narrowing treatment, covering 100 passing vehicles, at an intersection between an urban dual carriageway and an estate street where over a dozen fatal accidents occurred in the recent years. Traffic noise was also measured, both before and after lane narrowing. The traffic count data were analysed to show speed reduction by ca. $15 \mathrm{~km} / \mathrm{h}$, yet in all cases still above $50 \mathrm{~km} / \mathrm{h}$, which is the speed limit applicable to built-up areas in Poland. The analysis of the "before" and "after" noise maps showed only minor changes to the distribution of noise. The locations of these changes to the acoustic environment depended on the speed and volume of traffic and, much more importantly, on the topography of the surrounding area, the existing roadside layered landscape and the type of planted vegetation. The detailed analyses of the analysed parameters demonstrated that sustainable design of traffic calming measures on urban dual carriageways must consider not only the desired speed reduction but also the surrounding landscape and the local topography.

Keywords: lane narrowing; speed reduction; sustainable development; noise; local topography; acoustic environment; landscaping; roadside layered landscape

\section{Introduction}

The ever-growing number of motor vehicles and developments in the automobile sector result in faster driving which in adverse conditions may lead to road accidents [1,2]. As a remedy to this situation, various traffic calming measures have been developed in different countries [3-9]. According to WHO ([2], Chapter 1, Figure 1.1) an accident in which a vulnerable road user is hit by a car travelling at a speed greater than $50 \mathrm{~km} / \mathrm{h}$ carries a very high risk of a fatality. There are a number of factors influencing the speeds of travel, including the design class and parameters of the street and its importance in a given traffic system, vehicle type, driver personality traits, location in a built-up area, landscaping in the surrounding area, weather, time of the day $[4,6]$. Bearing this in mind, traffic calming schemes are implemented in built-up areas or specific, tailor-made measures are applied in places of exceptionally high accident rates (including changes to traffic management devices, i.e., signs and pavement markings) [4]. There are many different traffic calming measures, signs and markings to choose from, depending on the situation $[1,5,6]$. The primary objective of traffic calming is slowing down the traffic in a sensitive area in order to reduce the accident rate and the severity of injuries suffered by pedestrians [2]. Environmental impact of traffic is also mitigated as a result, including reduced fuel consumption, air pollution and traffic noise [1].

Lane narrowing that imposes a lateral shift is just an example of the most recommended traffic calming measures [1]. As a rule, drivers tend to drive faster on wider 
roads [3-6]. Therefore, each narrowing of the lane width slows down the traffic [6,7]. Road narrowing by pavement markings may also cause some slowing as narrower road ahead always influences driver's perception. That said, lane narrowing should always match the function and importance of the street in question [1]. In addition, speed limits imposed by the speed limit traffic signs (SLTS) must be applied reasonably, as otherwise they would tend to be ignored by drivers [1]. The effect of horizontal and vertical alignment on the speed of traffic was described in [10,11]. The effect of various traffic calming measures on the traffic speed in built-up areas was described, for example, in [12-16]. However, the actual effectiveness of traffic calming measures depends strongly on the class and importance of the street in question [1], personal traits, mood and perception of driver [2], frequency of the traffic calming treatments along the path of travel [3,5-7] and, last but not least, landscaping [17].

The effects of the applied traffic calming include reduction of traffic noise [1,18-21]. The degree of this reduction depends on a number of factors, including the type and importance of the street, speed of traffic, local topography, landscaping, land use [18-21]. Additionally relevant is the type of the road surface, composition of traffic, type of tires, etc. [22-26] and many other factors.

Noise generated by road traffic has a significant impact on the health and wellbeing of the local community, as demonstrated in $[5,19,22,27]$. A detailed study on the impact of noise on the wellbeing of people, resulting in irritation and sleep disturbances was reported in [28]. The above facts were considered by introduction of sound absorption classes for the street surroundings [29,30] and defining sound absorption coefficients for the roadside vegetation and guidelines for landscaping in the adjacent area [31,32]. The relevant factors include local topography, location of buildings, landscaping features in the adjacent area and vegetation (specifically the type, density and height) [33,34]. Studies on the effect of noise and its reduction on wellbeing of people in urban parks, taking into consideration bird sounds were carried out in several countries, including Australia [35], the Czech Republic [36] and Sweden [37]. The research findings vary from study to study. In the case of study areas located in natural urban landscape it was observed that in the presence of bird sounds people pay less attention to road traffic noise [35] yet only in the case of people who were generally insensitive to street noise. Interestingly, according to a Czech study on the walking speed along streets with adjacent vegetation with audible bird sounds pedestrians tend to walk slower in spring [36]. On the contrary, no effect on the walking speed or wellbeing was noted in autumn with audible bird sounds and with or without street noise. A study carried out in Sweden [37] showed that large highly natural green areas such as urban forests, classified as high naturalness areas, had a better effect on wellbeing of people at different ages than urban parks, classified as low naturalness areas.

The distribution of noise in built-up areas depends also on the type of traffic calming measure [38-40], placement of speed limit signs alone [41] or the method and technologies applied in street or intersection upgrading projects [24].

Modelling of noise distributions in built-up areas was the subject of [42] with due consideration given to different traffic systems and various road factors. The authors considered various independent variables, including street location and importance, traffic and geometry parameters, siting of traffic management devices and also, a novelty: land use and landscaping of the surrounding area. Owing to their suitability for urban planning purposes the developed models can be used for estimating noise pollution in any town or city. A different approach to noise distribution modelling in urban areas was presented in [43]. In addition to the effect of topography and vegetation the authors considered also variations in the atmospheric boundary layer and free troposphere depending on the wind speed and direction.

A review of the state of research on the problem in question is provided in the introduction, followed by the description of the study area in Section 2. Considering the complexity of noise distribution in built-up areas with various traffic calming measures in place the authors chose an urban dual carriageway near a T-intersection as the study area. 
Traffic and speed counts and noise measurements were carried out before and after lane narrowing, the results of which are presented and analysed in Section 3. Section 4 presents the discussion of results with due consideration given to their variation. The research conclusions are given in Section 5, the final section of this article.

\section{Materials and Methods}

\subsection{Subject of Study and Study Area}

The study area is a section of an urban dual carriageway near a non-signalised Tintersection with occasional pedestrian traffic across the street. It is an out of centre location, part of a route linking an uptown district with the downtown area (Figure 1-marked in orange). It provides an alternative route to the congested parallel trunk road DK10 with the same cross-section parameters (Figure 1-marked in green). In peak hours, quite frequently, drivers divert to this route from the DK10 trunk road using it as a shortcut to the city centre. The travel lanes on both these streets were all $3.5 \mathrm{~m}$ wide. The statutory speed limit for built-up areas was exceeded on both streets.

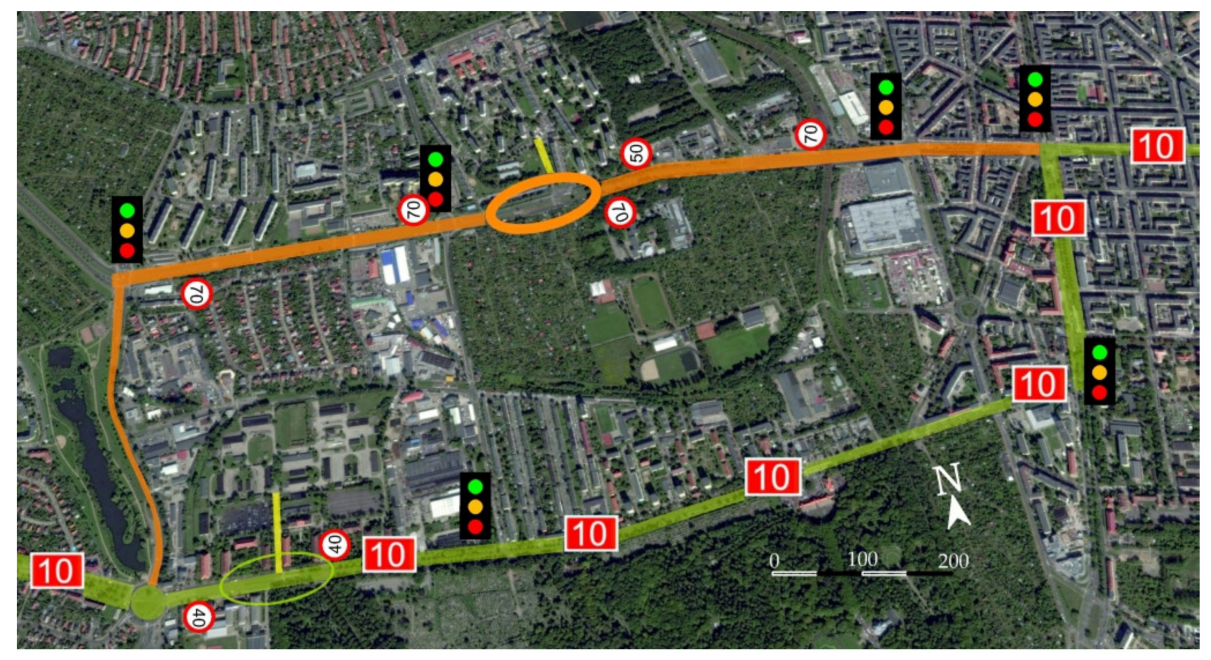

Figure 1. Study area shown on a background of a satellite image of a part of the city of Szczecin, Poland. (Source: own work of the authors using Google Earth satellite imagery [44]).

The drivers are tempted to speed up by the long dual carriageway sections between signalised intersections and lack of residential buildings along walkways. In the recent years a few fatal accidents occurred on a pedestrian crossing at one T-intersection (encircled in orange in Figure 1). Taking this into consideration, the city authorities decided to implement lane narrowing, reducing the width of each travel lane by ca. $0.5-0.6 \mathrm{~m}$ just before the problematic crossing. A similar treatment was implemented on a few other city streets where no accidents occurred before or after lane narrowing (encircled in green in Figure 1). Signalised intersections and SLTS locations are also shown by symbols in Figure 1. Marked in yellow are local transverse streets with few cars and only occasional pedestrian traffic.

The speed limit on the section between the signalized intersections was $70 \mathrm{~km} / \mathrm{h}$. Lane narrowing is communicated to the drivers by appropriate traffic signs. Each sign alerting the drivers of the oncoming lane narrowing, i.e., traffic safety warning sign U-21 is accompanied by three short traffic separators U-25 (Figure 2), oriented at $45-80^{\circ}$ in relation to a line perpendicular to the lane axis. The U-21 signs accompanied by U-25 separators were placed in three places on both sides along each roadway. 


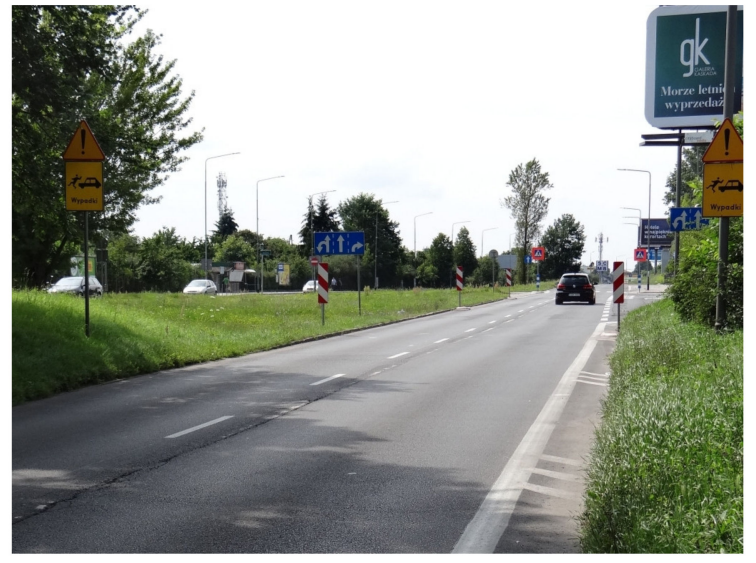

(a)

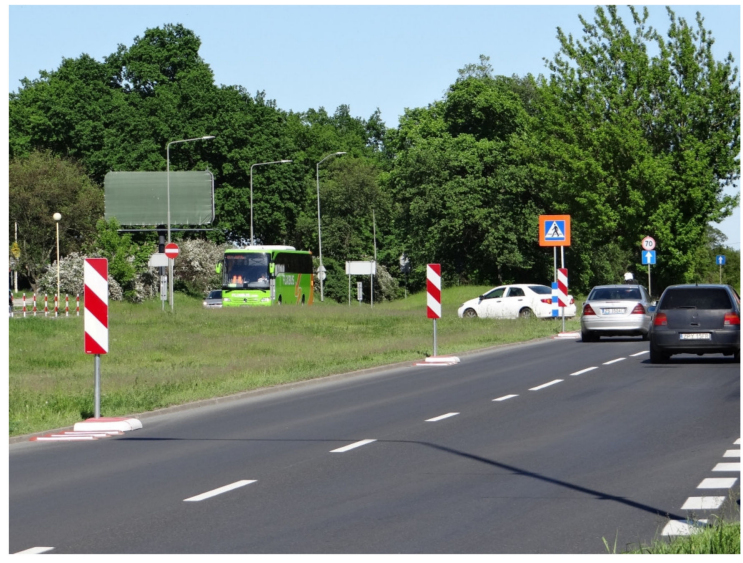

(b)

Figure 2. Method of alerting the drivers of the oncoming lane narrowing (three signs U-21 accompanied by U-25 separators): (a) Westbound carriageway leading from the city centre; (b) Eastbound carriageway leading to the city centre.

The local topography and residential buildings in the vicinity of the study area are shown in Figure 3.

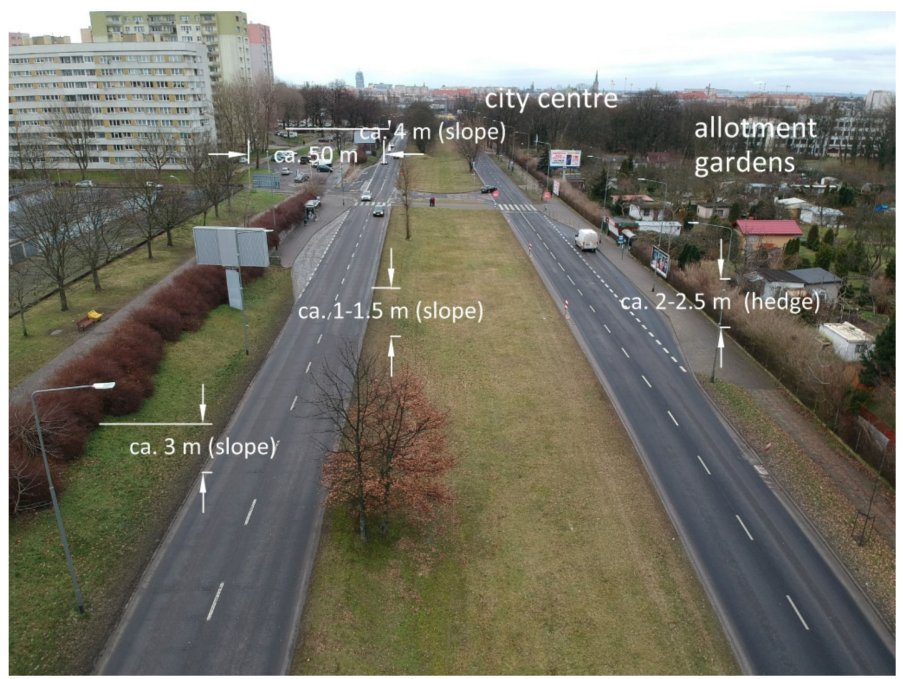

Figure 3. Local topography of the study area (bird's-eye view of the analysed section of the street viewing towards the city centre).

On the one side of the approach to the lane narrowing treatment on the westbound carriageway there is a steep, ca. 3-4\% up slope and vertical curvature limiting the view of the road ahead. On this section the westbound carriageway runs in a ca. 3-4 $\mathrm{m}$ deep cut. The above-mentioned vertical curvature is followed by a ca. $1 \%$, i.e., gentle longitudinal slope (Figure 4). Behind the cutting slope there are apartment blocks, spaced from the street by over 50 metres (Figure 3). On the other side of the street there are allotment gardens separated from the walkway by a high and thick hedge (ca. 2-2.5 $\mathrm{m}$ high). The area of the allotment gardens lies ca. $0.5 \mathrm{~m}$ below the eastbound carriageway. 


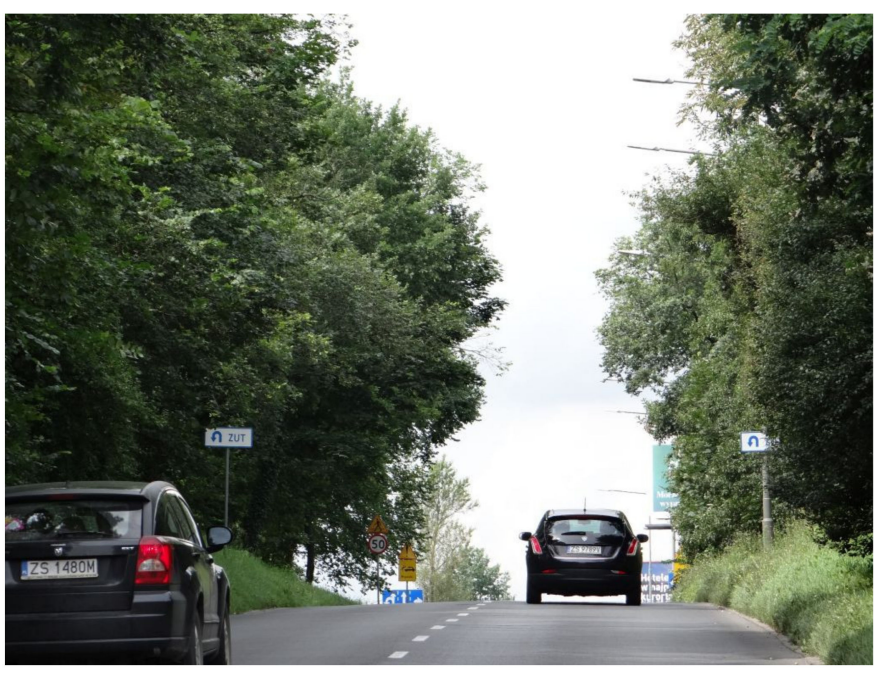

Figure 4. Approach to the study area on the westbound carriageway leading from the city centre, running in a cutting with ca. $3-4 \%$ longitudinal slope.

The median strip has an uneven surface with a regular 1-1.5 $\mathrm{m}$ high (taking the surface of the eastbound carriageway as a reference elevation) slope closer to the westbound carriageway. The surface of the median strip is generally covered with grass only, except for the part after the T-intersection driving to the city centre (in the background of the image in Figure 3) where there are large trees and numerous shrubs (Figure 4).

The strip between the westbound carriageway and the walkway running along it features strongly varied topography and landscaping. The walkway runs behind the slope, ca. 3-4.5 $\mathrm{m}$ above the carriageway surface. It is separated from the carriageway by a slope occupied by numerous dense shrubs and low trees with a round-shaped crown. Behind the walkway there are the above-mentioned apartment blocks and row garages located in an area lying below the surrounding land. The buildings and garages are separated from the walkway by a strip of vegetation include ca. 7-10 $\mathrm{m}$ high, i.e., medium sized trees with thick round crowns. The garages are accessed from a side street after T-intersection.

No major or even minor accidents without injuries occurred in the period of three years after implementation of lane narrowing on this problematic intersection.

\subsection{Measurement Method}

In order to check if the applied lane narrowing caused a speed reduction with a likely change to the acoustic environment around the urban dual carriageway under analysis, traffic and speed counts accompanied by noise measurements were carried out before and after implementation of the traffic calming treatment. All measurements of traffic volume, speed and noise were made on working days (Tuesday and Wednesday), from 10.00 to 14.00, on a sunny day. The traffic counts were carried out simultaneously on the two carriageways by means of SR4 traffic detection devices featuring simultaneous collection of speed and volume data. During the speed and traffic volume measurements, noise was measured in parallel. Synchronised speed and volume counts were carried out on a section before a pedestrian crossing at a non-signalised T-intersection. The location of the test area is shown in Figure 3. Since all the traffic data were collected at the same time and considering marginal contribution of the estate street to the traffic volume, the traffic volume was taken at the same level on all the test sections, i.e., before the narrowing, at the intersection and after the narrowing. The volume of traffic on the analysed street was $1100 \mathrm{veh} / \mathrm{h}$ on the westbound carriageway and $750 \mathrm{veh} / \mathrm{h}$ on the eastbound carriageway. On both carriageways the $\mathrm{HGV}$ percentage varied from $3.7 \%$ to $7.5 \%$. In line with the principles of experimental research, homogeneity of the input data is prerequisite to obtaining reliable results and hence the only variable was the count location, i.e., "before", "within" and "after" narrowing of each carriageway, as shown in Figure 5. 


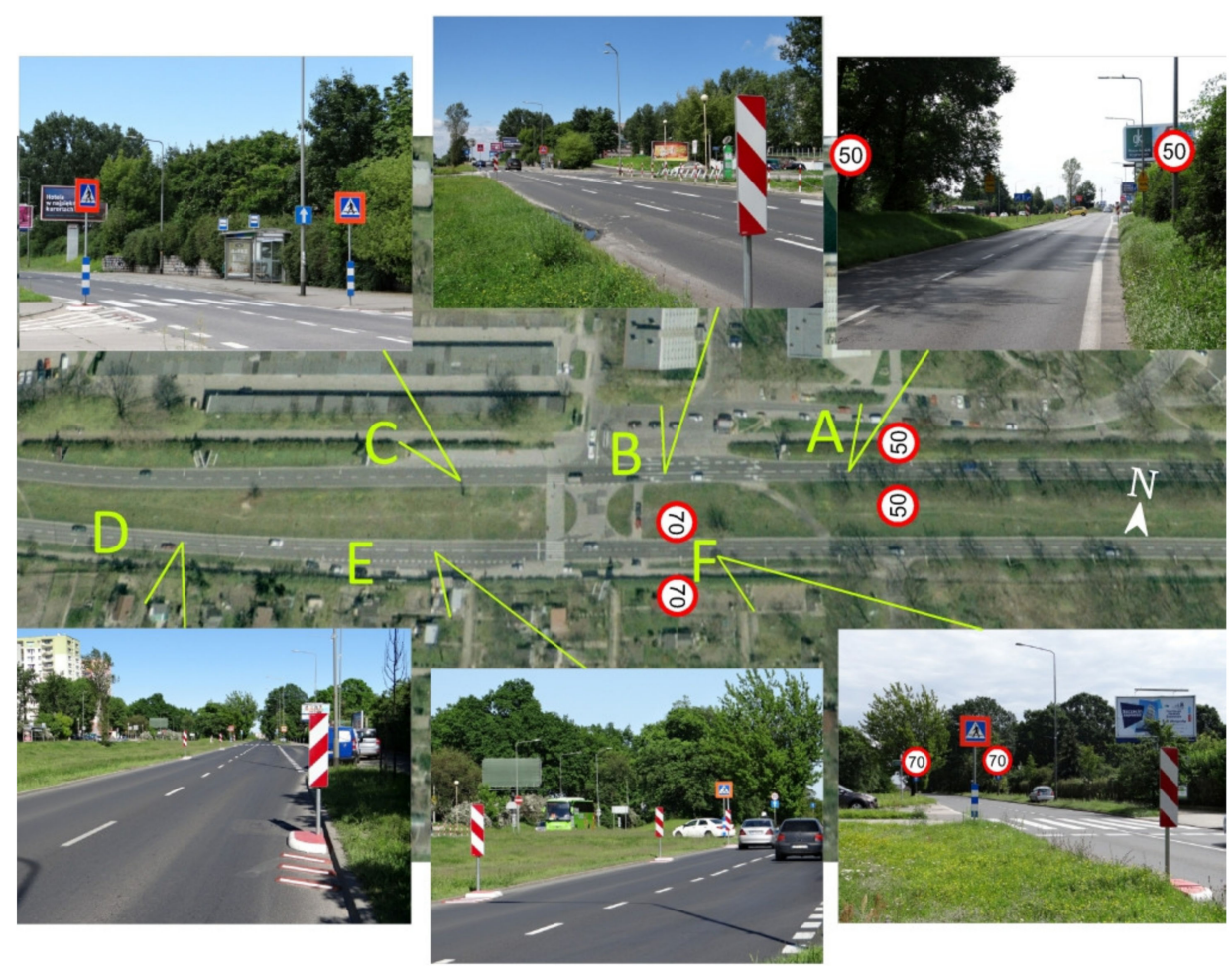

Figure 5. Location of the test sections on both carriageways under analysis: A, B and C-test sections on the westbound carriageway preceded by a ca. $600 \mathrm{~m}$ long straight section of the road; D, E and $\mathrm{F}$ - test section on the eastbound carriageway preceded by a ca. $130 \mathrm{~m}$ long straight section starting from the signalised intersection to the west.

Video recording was also used during the counts for selection of the collected traffic data, i.e., to select situations with only one vehicle moving on either lane of one carriageway. Video recording allowed to filter out cases when two vehicles travelled simultaneously on the same carriageway. In this way free traffic flow situation was obtained by screening vehicles with a 7-s headway and free adjacent lane, in accordance with the principles given in [11]. The traffic counts were carried out during weekday peak hours, continued until obtaining at least 100 count data in free flow traffic condition on each test section. This amount of the input data ensured robustness of further analyses.

The assumptions of the study included additional, parallel traffic counts of passenger cars travelling on the fast lane and HGVs or busses travelling on the slow lane. The counts were limited to the narrowed section on both lanes. Both vehicles had a $7 \mathrm{sec}$. headway on a narrowed carriageway on both lanes.

This assumption ensured reliability of analyses of the implemented narrowing on the speed of traffic.

Noise was measured with SVAN 971 class 1 sound level meter with FAST time constant and A weighting in compliance with IEC 61672-1. The meter is designed for monitoring the level of noise in different environments. In order to obtain reliable results, all the measurements were carried out under stable weather conditions, i.e., dry surface, dry weather, no frost, etc., in compliance with ISO 1996-2 [45]. Considering possible traffic volume variations and small HGV percentage the test duration was 15 min (divided into 5 -min spans) which is roughly the waiting time at a bus stop. The meters were positioned $1.5 \mathrm{~m}$ above the ground to represent the ear height of the pedestrians walking along either side of the road and standing at the bus stop, in order to check for noise as actually sensed by people. The meters were sited on the walkways running on both sides of the road. On the walkway along the eastbound carriageway the meters were placed at a constant distance of $3 \mathrm{~m}$ from the road edge. In the case of the walkway along the westbound carriageway this distance varied between 5 and 10 metres due to the presence of the slope separating 
the walkway from the road. The meters were calibrated before each measurement. All the measurements were carried out in a sunny weather at ca. $18-20{ }^{\circ} \mathrm{C}$.

Noise measurements were carried out also for the situation before the lane narrowing treatment, yet only on two sections before and after the intersection, relative to the sections on the approach to and past the lane narrowing. It must be noted though that the section leading to the intersection coincided with the lane narrowing section over a half of the overall length.

\subsection{Research Methods}

The following traffic parameters were chosen for further analyses: $v_{85}, v_{a v}$ and standard deviation $s$ and, in addition, also $\Delta v_{85}$. First all the samples were checked for normality. This check was carried out with the conventional Kolmogorov-Smirnov goodness of fit test (K-S test) assuming continuous function of random variables of the collected speed data. Shortly before implementation of the traffic calming treatment speed measurements were carried out on both carriageway on the approach to the T-intersection, i.e., on section A-B on the westbound carriageway and on section D-E on the eastbound carriageway. Considering smooth flow of traffic at the intersection before the traffic calming treatment separate speed measurements past the intersection were skipped. Since the study concerned free-flow traffic, it was assumed that all vehicles drove through the intersection with the same speed. Next it was assumed that appropriate comparative analyses will be performed for the obtained results in relation to speed reduction using for this purpose the two-sample $\mathrm{K}-\mathrm{S}$ test and median test.

In addition, the noise data were subjected to analyses. Two noise parameters were chosen for analytical purposes: equivalent continuous sound level Leq and the maximum noise level Lmax (all expressed in dBA). Both Leq and Lmax were calculated automatically by the meter during measurements. Lmax values are also analysed in some situations, to check short-term impact of sound emitted by a noisy vehicle.

Drawing up noise maps was also part of the research. Consideration was given to the very complex local topography, varying longitudinal inclination on both carriageways, volume and speed of traffic, cut depth, row garages lying in a small depression right behind the walkway, strongly varied landscaping, roadside layered landscape and varied distribution of apartment blocks rising at a distance of $50 \mathrm{~m}$ from the carriageway edge. As part of the study, daytime noise maps were to be drawn up for the "before" and "after" situation. The purpose was to assess whether lane narrowing with the consequential slowing effect influenced the distribution of noise around the analysed T-intersection.

\section{Results}

\subsection{Speed Data}

The speed distributions are presented in Figures 6 and 7 and in Table 1. Normality of the speed samples was ascertained for all the test sections by means of the KolmogorovSmirnov goodness-of-fit test (K-S test) (Table 1). The tabled speed data include also additional measurements at lane narrowing sites. These additional measurements concern situations when a passenger car travelled on the fast lane parallel to a HGV travelling on the slow lane along the test sections B and D. The analysis of the data presented in Figures 6 and 7 and in Table 1 showed a large dispersion of results for both "before" and "after" speeds. Only the additional average speeds (relating to vehicles travelling parallel in adjacent lanes) are close to the speed limit of $50 \mathrm{~km} / \mathrm{h}$ posted on the SLTS sign. On the other test sections the average speeds exceed this limit. The 85th percentile speeds, in turn, significantly exceed the speed limit posted on the SLTS sign on all the test sections. The principles for determining the speed posted on the SLTS sign are recognised internationally, based on the results of the studies carried out by Solomon [46]. It was assumed then that the posted speed should relate to the 85th percentile speeds of travel past the sign location. According to these principles any vehicles travelling faster than that pose a risk of accident, which occurred multiple times in the case under analysis. In Figures 6 and 7 speeds in 
excess of $50 \mathrm{~km} / \mathrm{h}$ are marked in green, showing a very large range on all the analysed test sections except for the test section No. F with a posted speed limit of $70 \mathrm{~km} / \mathrm{h}$ (Figure 1).

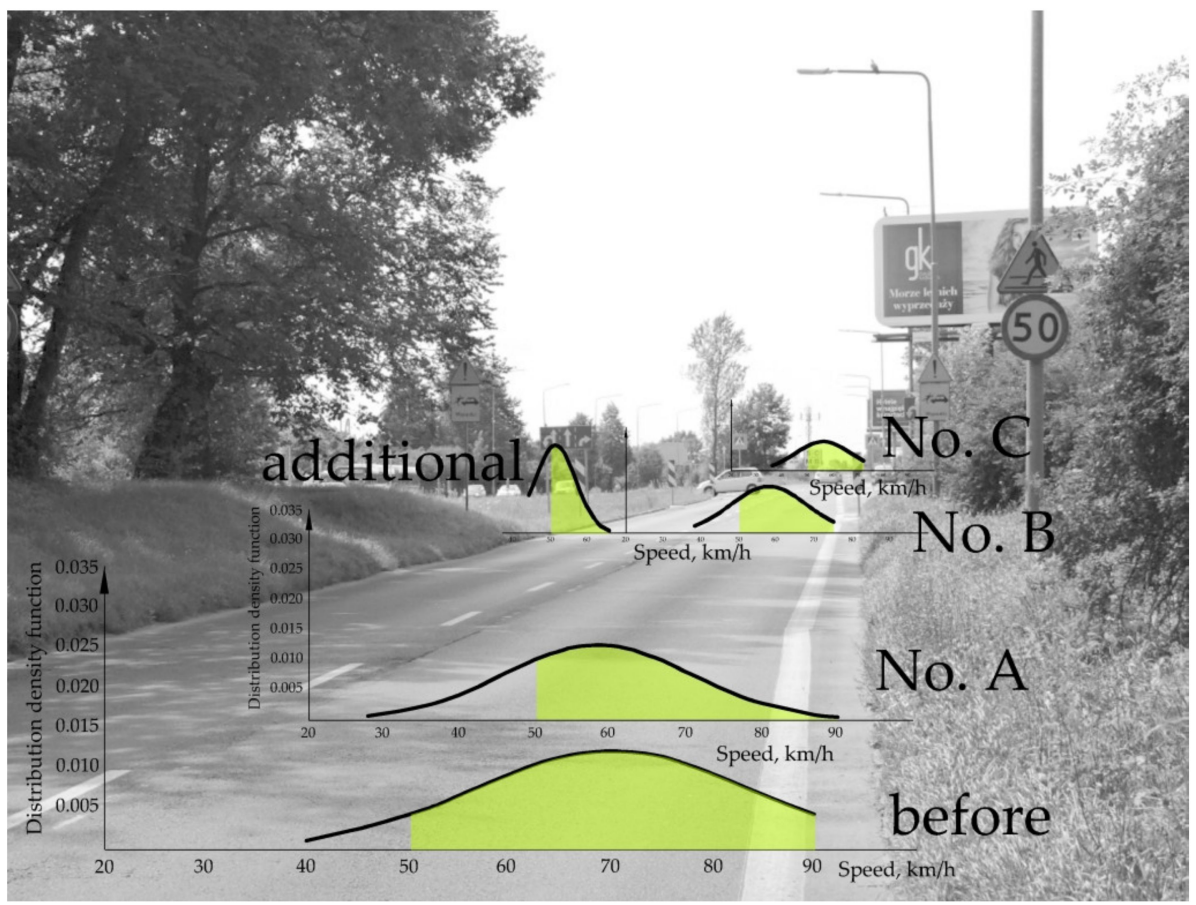

Figure 6. Gaussian curve of speed distribution on the test sections on the westbound carriageway (ca. $600 \mathrm{~m}$ approach along a straight section).

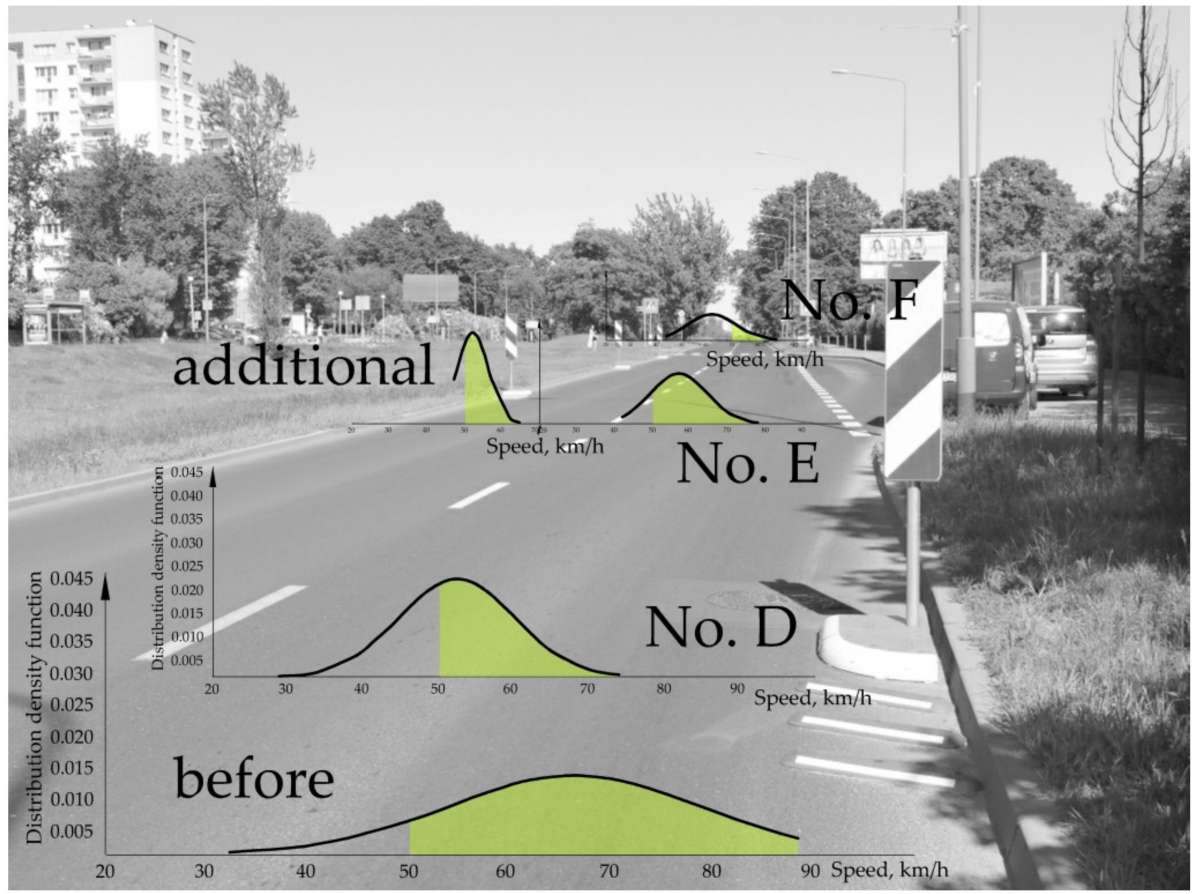

Figure 7. Gaussian curve of speed distribution on the test sections on the eastbound carriageway (ca. $130 \mathrm{~m}$ approach along a straight section). 
Table 1. Speed results: measured and obtained from the statistical tests.

\begin{tabular}{|c|c|c|c|c|}
\hline Test Section & Average Speed, km/h & $\begin{array}{l}\text { 85th Percentile Speed, } \\
\text { km/h }\end{array}$ & $\begin{array}{l}\text { Standard } \\
\text { Deviation }\end{array}$ & $\begin{array}{c}\text { Goodness-of-Fit K-S Test, } \\
\lambda_{\alpha}=1.36\end{array}$ \\
\hline \multicolumn{5}{|c|}{ ca. $600 \mathrm{~m}$ long straight approach section } \\
\hline Before treatment & 70.7 & 86.7 & 12.9 & 0.78 \\
\hline $\begin{array}{l}\text { No. A before } \\
\text { narrowing }\end{array}$ & 58.2 & 70.7 & 12.5 & 0.42 \\
\hline No. B before crossing & 57.8 & 70.4 & 10.2 & 0.36 \\
\hline No. C after narrowing & 56.2 & 70.5 & 10.9 & 1.09 \\
\hline $\begin{array}{l}\text { No. B (additional } \\
\text { measurements) }\end{array}$ & 51.2 & 56.9 & 5.4 & 1.01 \\
\hline \multicolumn{5}{|c|}{ ca. $130 \mathrm{~m}$ long straight approach section } \\
\hline Before treatment & 66.0 & 81.4 & 11.7 & 0.46 \\
\hline $\begin{array}{l}\text { No. D before } \\
\text { narrowing }\end{array}$ & 52.2 & 59.0 & 7.7 & 0.50 \\
\hline No. E before crossing & 56.7 & 62.7 & 7.5 & 0.66 \\
\hline No. F after narrowings & 61.5 & 69.5 & 9.6 & 0.67 \\
\hline $\begin{array}{l}\text { No. E (additional } \\
\text { measurements) }\end{array}$ & 51.9 & 54.6 & 4.1 & 0.38 \\
\hline
\end{tabular}

The city authorities expected that the traffic will slow down as a result of lane narrowing; this was achieved. This can be seen from a comparison of the speeds on all the test sections, i.e., A, B and C with the "before" speed data (Table 2). However, the "after" values are not what was expected by the city authorities. Except for the additional measurements, the 85th percentile speeds substantially exceed the speed limit posted on the SLTS sign.

Table 2. Speed reductions before the pedestrian crossing.

\begin{tabular}{|c|c|c|c|c|}
\hline \multirow{2}{*}{ Test Section } & \multirow{2}{*}{ Average Speed, km/h } & \multirow{2}{*}{$85 \%$ Percentile Speed, $\mathrm{km} / \mathrm{h}$} & \multicolumn{2}{|c|}{ Reduction Speed } \\
\hline & & & $\Delta v_{a v}$ & $\Delta v_{85}$ \\
\hline \multicolumn{5}{|c|}{ ca. $600 \mathrm{~m}$ long straight approach section } \\
\hline Before treatment & 70.7 & 86.7 & \multirow[b]{2}{*}{12.9} & \multirow[b]{2}{*}{16.3} \\
\hline No. B before crossing & 57.8 & 70.4 & & \\
\hline Before treatment & 70.7 & 86.7 & \multirow{2}{*}{19.5} & \multirow[b]{2}{*}{29.8} \\
\hline $\begin{array}{c}\text { No. B (additional } \\
\text { measurements) }\end{array}$ & 51.2 & 56.9 & & \\
\hline \multicolumn{5}{|c|}{ ca. $130 \mathrm{~m}$ long straight approach section } \\
\hline Before treatment & 66.0 & 81.4 & \multirow{2}{*}{9.2} & \multirow{2}{*}{18.7} \\
\hline No. E before crossing & 56.7 & 62.7 & & \\
\hline Before treatment & 66.0 & 81.4 & \multirow{2}{*}{14.1} & \multirow[b]{2}{*}{26.8} \\
\hline $\begin{array}{l}\text { No. E (additional } \\
\text { measurements) }\end{array}$ & 51.9 & 54.6 & & \\
\hline
\end{tabular}

Additionally, speeds are presented in ranges in Figure 8. The analysis of the results presented in the Tables 1 and 2 and in Figure 8 shows that speed reduction was nevertheless achieved, as compared to the period before the implementation of the slowing treatment when fatal accidents did occur in this area. It must be noted though that even the 25th percentile "after" speeds exceed the speed limit of $50 \mathrm{~km} / \mathrm{h}$ posted on the SLTS sign. 


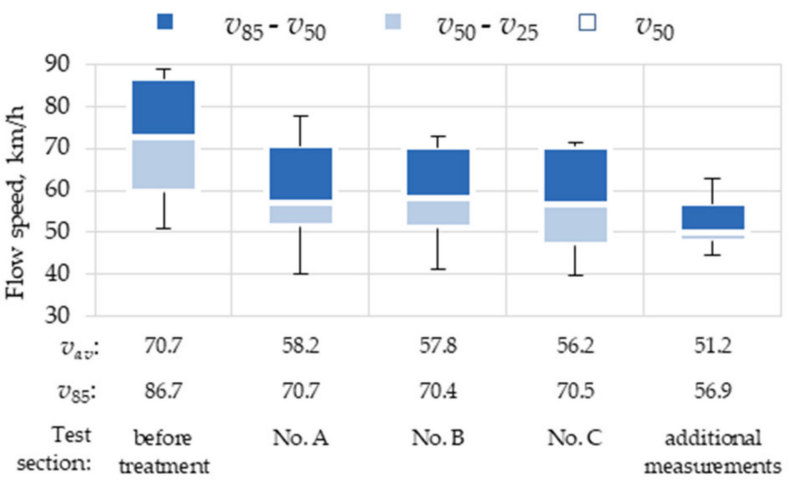

(a)

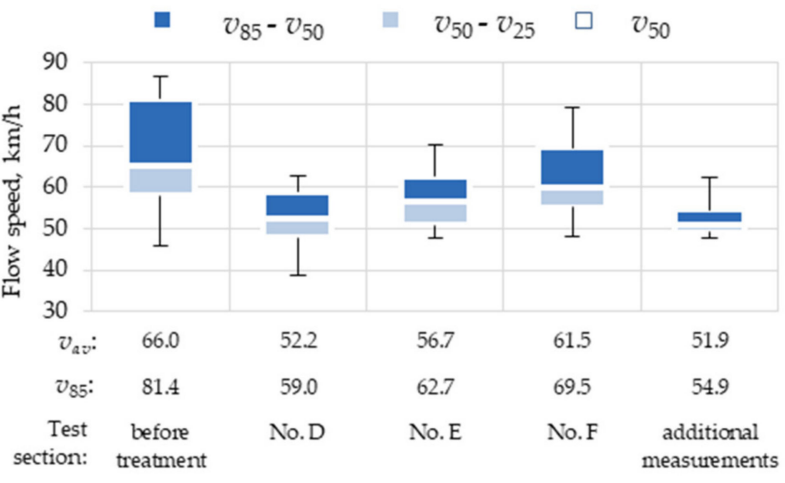

(b)

Figure 8. Estimated speed ranges in $\mathrm{km} / \mathrm{h}$ : (a) On the test sections on the westbound carriageway preceded by a ca. $600 \mathrm{~m}$ long straight section of the road; (b) on the test sections on the eastbound carriageway preceded by a ca. $130 \mathrm{~m}$ long straight section of the road.

\subsection{Noise Measurement Data}

The value of Leq allowed for the area under analysis was taken into consideration. As per the relevant European standards [47] in areas with multi-family and public accommodation occupancies noise levels must not exceed $65 \mathrm{~dB}(\mathrm{~A})$ during daytime. In addition, in the area occupied by allotment gardens, i.e., recreational area the maximum allowable noise level is $65 \mathrm{~dB}(\mathrm{~A})$. As mentioned earlier, the measurement time was limited to $15 \mathrm{~min}$ and the value of Leq was obtained automatically by using the built-in feature of the sound level meter. The data given in Table 3 show exceeding of the maximum allowable noise level of $65 \mathrm{~dB}(\mathrm{~A})$. Considering the above, the results are presented in Figure 9 as a percentage above the allowable noise level.

Table 3. Compilation of noise data.

\begin{tabular}{ccc}
\hline Test Section & Leq, $\mathbf{d B}(\mathbf{A})$ & Lmax, $\mathbf{d B}(\mathbf{A})$ \\
\hline ca. 600 m long straight approach section & & \\
Before treatment before intersection & 63.1 & 80.7 \\
Before treatment after intersection & 62.8 & 72.8 \\
No. A before narrowing & 71.8 & 86.4 \\
No. B (before crossing) & 70.6 & 90.7 \\
No. C after narrowings & 72.4 & 86.7 \\
ca. 130 m long straight approach section & & \\
Before treatment before intersection & 63.1 & 79.3 \\
Before treatment after intersection & 63.6 & 76.3 \\
No. D before narrowing & 70.6 & 90.8 \\
No. E (before crossing) & 71.7 & 91.1 \\
No. F after narrowings & 74.0 & 100.3 \\
\hline
\end{tabular}

Figure 10, in turn, presents calculated noise ranges on the analysed test sections. Considering the very strongly varied local topography and landscaping the noise measurements were carried out before the traffic calming treatment at two sites before and after the intersection on the walkways running along both carriageways. As mentioned, before the traffic calming treatment on the sections leading to and past the intersections the speeds were taken at the same level, since only vehicles travelling in free-flow condition (i.e., with no car ahead of them) were considered. 
(a)

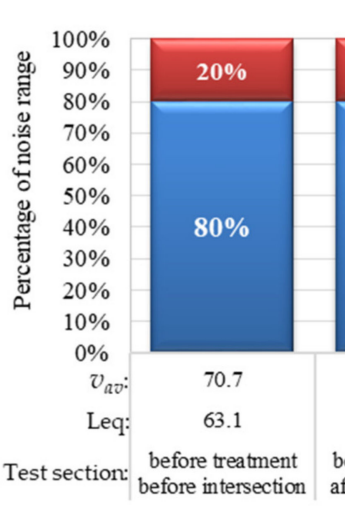

曰 $\leq 65 \mathrm{~dB}(\mathrm{~A}) \quad \square=65 \mathrm{~dB}(\mathrm{~A})$
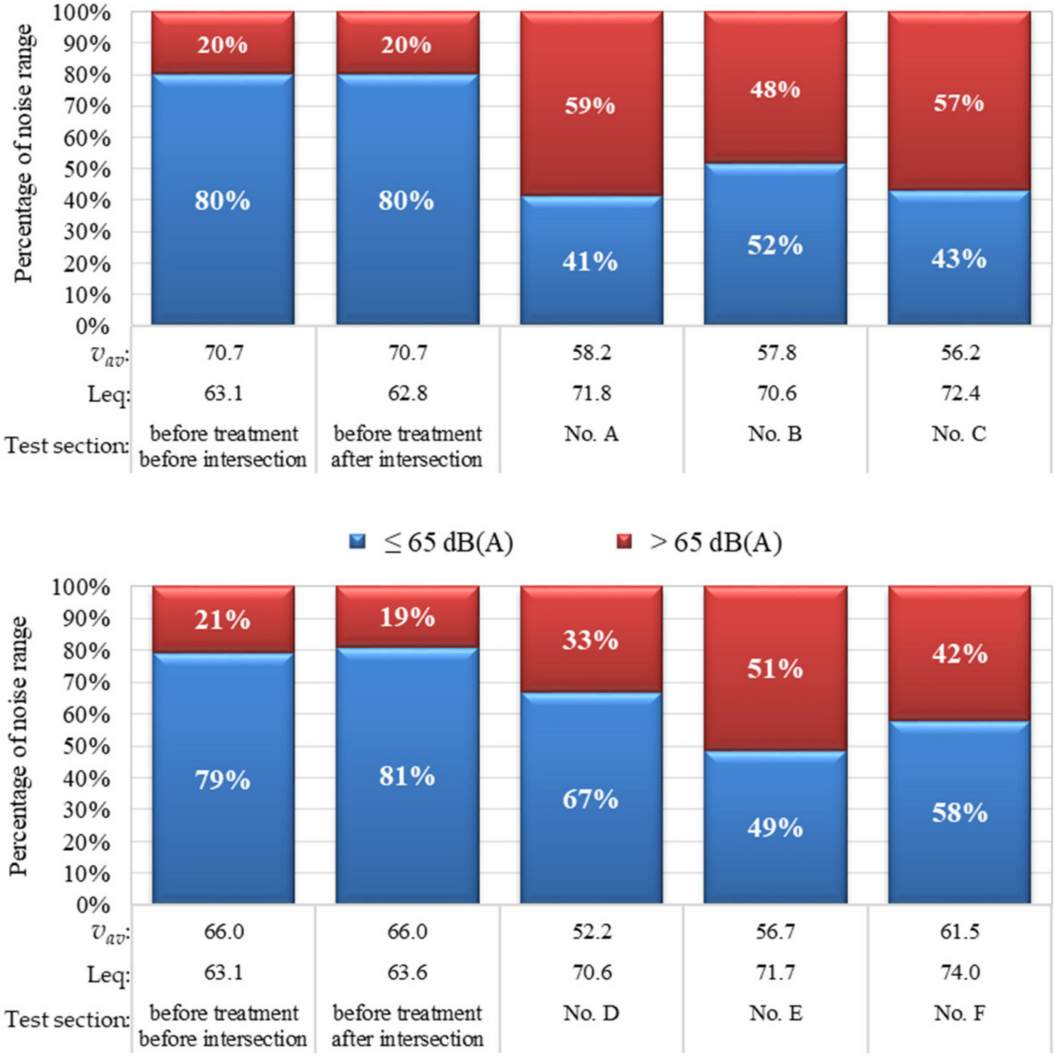

Figure 9. Percentage shares of noise on the analysed test sections: (a) Westbound carriageway-ca $600 \mathrm{~m}$ long straight approach section of the road; (b) Eastbound carriageway-ca. $130 \mathrm{~m}$ long straight approach section of the road.

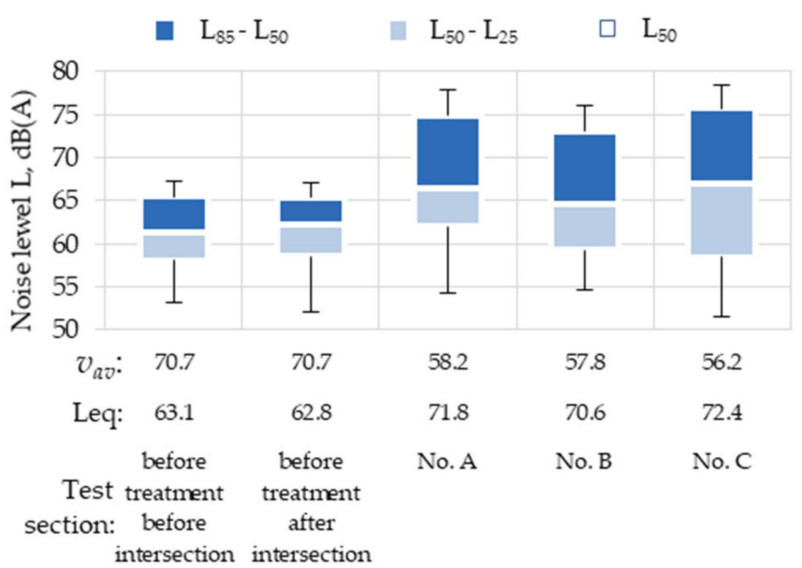

(a)

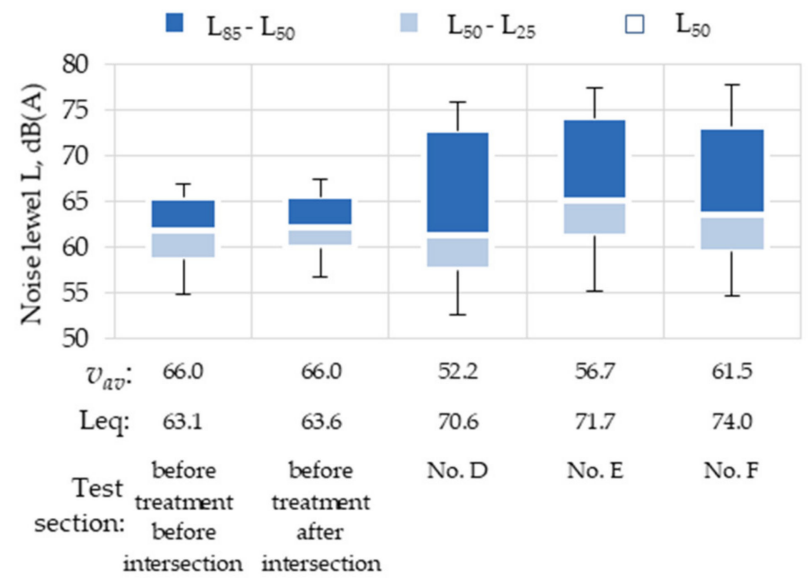

(b)

Figure 10. Estimated noise ranges on the test sections, $d B(A)$ : (a) Westbound carriageway-ca. $600 \mathrm{~m}$ long straight approach section of the road; (b) Eastbound carriageway—ca. $130 \mathrm{~m}$ long straight approach section of the road.

\subsection{Noise Maps in the Study Area}

Considering the above presented noise data, the authors drew up noise maps taking the input data including traffic volume and average speed, profile of both carriageways, cutting depths, common space conditions (including topography with the utilisation of 
digital elevation models, location of buildings, type of vegetation and landscaping). The resulting noise maps showing the acoustic environment before and after the lane narrowing treatment on the urban dual carriageway under analysis are presented in Figures 11 and 12, respectively, which also give the average speed values on the respective test sections. In addition, the respective test sections are separated by black lines to highlight their location in the area. The traffic level on the subsidiary road leading to the analysed T-intersection was taken at ca. 70-100 veh/ $\mathrm{h}$, this including passenger cars only. The garages serving the residential estate, lying in a natural depression (ca. $5 \mathrm{~m}$ below the surrounding land) are pictured in the NW corner in Figures 11 and 12. The two rows of garages are accessed from the subsidiary street through access points located $30 \mathrm{~m}$ and $50 \mathrm{~m}$ from the edge of the analysed dual carriageway.

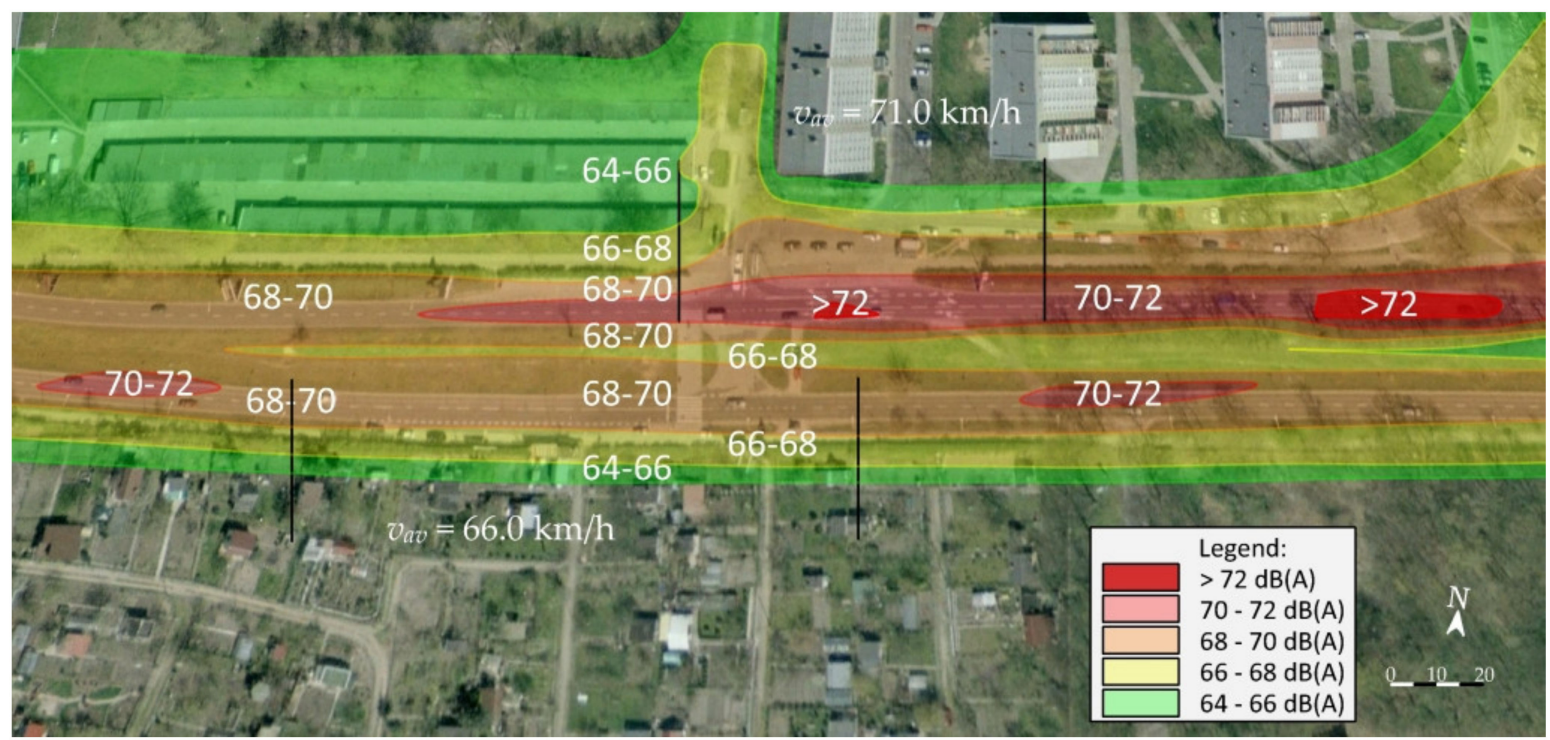

Figure 11. Noise map showing the situation before the implementation of the lane narrowing treatment on the analysed urban dual carriageway.

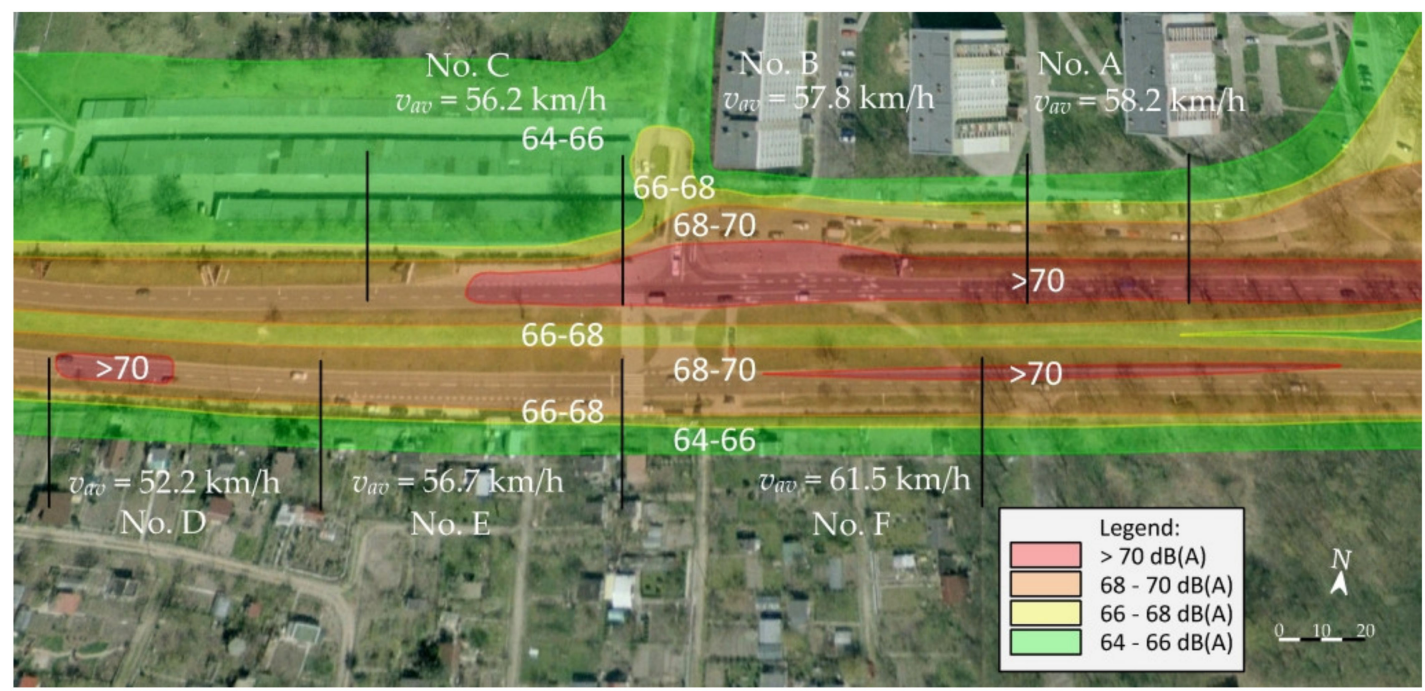

Figure 12. Noise map showing the situation after the implementation of the lane narrowing treatment on the analysed urban dual carriageway.

\section{Discussion}

Based on the analysed speed data, the implemented lane narrowing reduced the speed of traffic. However, the speed levels are still much above the speed limit posted on the SLTS 
sign. The detailed analysis of speed distributions showed a high percentage of excessive speeds, both as regards the average and 85th percentile speeds (Figures 6 and 7).

Therefore, the obtained reduction cannot be considered acceptable or satisfactory (Table 2). On the westbound carriageway over a long section between subsequent Tintersections the cars move in a steady flow of traffic with speeds that may cause unsafe road situations (Figure 6). Before implementation of the lane narrowing treatment, drivers tended to drive through the problematic intersection under analysis at the same speed at which they travelled along the long section of the street with $70 \mathrm{~km} / \mathrm{h}$ posted speed limit. They did not abide by the speed limit of $50 \mathrm{~km} / \mathrm{h}$ posted on the SLTS sign. This was the cause of fatal accidents at the pedestrian crossing. Based on the research results presented in $[48,49]$ at the vehicle speed of $70 \mathrm{~km} / \mathrm{h}$ the risk of a fatality in a vehicle/pedestrian accident is ca. 59\%, i.e., very high. Speeds at that level and even higher were noted in this area before implementation of the lane narrowing treatment.

Lane narrowing resulted in a considerable reduction of the speed of traffic, noted in the first two weeks (Figure 7). After that initial period the conditions of traffic changed and drivers tended to drive faster. Most probably this was due to habitual driving, as the drivers paid little attention to the implemented narrowing, most probably remembering scarce pedestrian traffic in this area. Lower speeds were then noted only on the test section No. B in additional speed measurements, i.e., when a passenger car drove parallel to a HGV or a bus. In such cases the drivers of the passenger cars slowed down before the crossing, maintaining a fairly steady traffic over a short section of the street, tending to accelerate depending on the signal displayed on the traffic lights over the westbound carriageway before the signalised intersection. The section of the street between the pedestrian crossing and the signalised intersection was ca. $250 \mathrm{~m}$ long.

Different traffic conditions were noted on the eastbound carriageway. Between the signalised intersection and lane narrowing location the drivers drove for ca. $130 \mathrm{~m}$ with a steady speed and accelerating only when restarting after having stopped before the intersection. If a green signal was displayed, they drove through the intersection without slowing down. These specific conditions were the primary cause of the lower speeds recorded in the test section No. D on the eastbound carriageway before the lane narrowing treatment. Next the drivers, bearing in mind occasional use of the pedestrian crossing and speed limit of $70 \mathrm{~km} / \mathrm{h}$ binding after the intersection, as posted on the SLTS sign, considerably accelerated on the subsequent test section No. E and No. F. However, similarly to the westbound carriageway, speeds close to $50 \mathrm{~km} / \mathrm{h}$ were noted only in the case of additional measurements. In this case also the scatter of the measured speed was the smallest (Figure 8).

This indicates that lane narrowing solely by pavement markings and a set of three U-21 signs accompanied by U-25 separators is not effective in reducing the speed of traffic and may be used only as a temporary solution before implementation of more effective measures. This was exactly what the city authorities did, i.e., after three years from implementation of the above-described lane narrowing treatment installed traffic lights at the intersection. Now pedestrians intending to cross the street activate the traffic lights manually by means of special detectors. As mentioned above, no major or minor vehicle/pedestrian accidents occurred in after implementation of lane narrowing, followed by installation of traffic lights on this problematic intersection.

As regards noise measurements, the Leq values were much lower and much less scattered in the "before" period (Table 3 and Figure 10). This is attributed to a steady flow of traffic, even though the driving speeds were higher. Being aware of only occasional pedestrian traffic on the crossing the drivers did not slow down when approaching the T-intersection under analysis and did not shift the gear, which resulted in considerably lower Leq values, as compared to the situation after implementation of the lane narrowing treatment. However, it must be noted that noise was measured over a period of only $15 \mathrm{~min}$. The reported Leq value was calculated automatically by the meter for that time span only. 
Much higher noise levels were noted after lane narrowing due to braking and acceleration and shifting gear by the drivers travelling along the successive test sections on both carriageways. The differences between the individual data were particularly large on the test section No. C, i.e., on the approach to the signalised intersection. The flow of traffic depended to a great extent on the displayed signal, visible to the drivers from a large distance. The scatter of results was even greater on the test section No. D, i.e., acceleration section after the stop line before the signalised intersection and when the drivers drove at a high speed through this section, seeing a green light ahead.

Despite similar average speeds on the test sections after lane narrowing the Leq values differ also between the two carriageways of the road. This is because the westbound carriageway runs in cut and thus the similar noise levels on the subsequent sections $\mathrm{A}, \mathrm{B}$ and $\mathrm{C}$ can be attributed to the effect of the surrounding slopes. On the eastbound carriageway, in turn, there are hedges along the walkways, separating the allotment gardens from the right-of-way. Furthermore, the adjacent land is flat on both sides of the eastbound carriageway with only a slight, i.e., ca. $0.5 \mathrm{~m}$ depression in the area of allotment gardens. It is probably these conditions that resulted in the varied scatter of individual noise levels.

One should also bear in mind, that automatic noise measurements are representative of the overall noise at a specific site influenced by a number of factors, including, besides the road traffic, also the adjacent vegetation, reflections of the sound waves from the built features located in the allotment gardens, retaining wall, garages, etc. [45,47,50]. In addition, the parameters of greenery have a considerable bearing on the level of noise measured at a given point on the walkway, including species of trees and shrubs, their distribution, height, crown spread, shape of leaves and density of branches [51-53]. According to the research results published in $[51,53]$ appropriate configuration of planted vegetation, i.e., by using different species and sizes, is highly relevant to air pollution and propagation of traffic noise. With vegetation limited to the lawn and trees located thereon, the propagation of the sound wave will be discontinued, yet air pollution will impact the comfort of pedestrians. On the other hand, a hedge accompanied by trees separating the carriageway from the pedestrian walkway may reduce air pollution in the walkway area depending on the hedge height. A human height hedge will, for example, be effective in reducing both noise and air pollution. Conversely, lower hedges will not be effective in reducing air pollution [50,54-56]. In addition, trees of varying species and height will mitigate road noise and result in lower levels of noise actually reaching the pedestrian's ear [53]. These observations and findings can be useful in explaining the variation of the measured noise levels presented in Figures 9 and 10.

Attention is also drawn to the Leq and Lmax values obtained on the walkways on the sections parallel to the existing bus stops, i.e., sections No. C and No. E. In both cases the pedestrian waiting at the bust stop is exposed to exceptionally high noise levels which was not the case before implementation of the lane narrowing treatment.

However, based on the findings of this study and presented in the literature on the subject one should reasonably expect multiple effects of traffic calming treatments, in addition to the speed reduction being the primary objective. Therefore, the designers should take an interdisciplinary approach and analyse also the noise and air pollution levels resulting from the obtained speed reduction. In addition, the authors are of the opinion in choosing the traffic calming measures one should consider the street as a whole, i.e., taking into account the street landscaping and utilising the topographical information obtained, for example from GIS and location data concerning the residential developments in the vicinity. This approach to selection of traffic calming measures follows the principles of sustainable development and care for surrounding environment.

A slightly different approach should be applied in the analysis of the noise maps presented in Figures 11 and 12. The noise distribution results do not concern the measurement point and its immediate vicinity. On noise maps noise distribution is presented by means of $5 \mathrm{~dB}(\mathrm{~A})$ contour lines with equal noise levels, ignoring any variations between them. In order to link the point measurements on the walkways the authors applied $2 \mathrm{~dB}(\mathrm{~A})$ steps 
to represent not only the local topography but also, and more importantly, the effect of the roadside layered landscape on the noise distribution. This is because the noise levels had a different distribution along the road before the implementation of the lane narrowing treatment (Figure 11). In the case of a road running in a cut the sound wave is kind of directed upwards, concentrating between the slopes. This being so, vegetation planted on the slopes in a layered configuration (Figure 13) reduces the level of noise generated by vehicles travelling with high speeds.

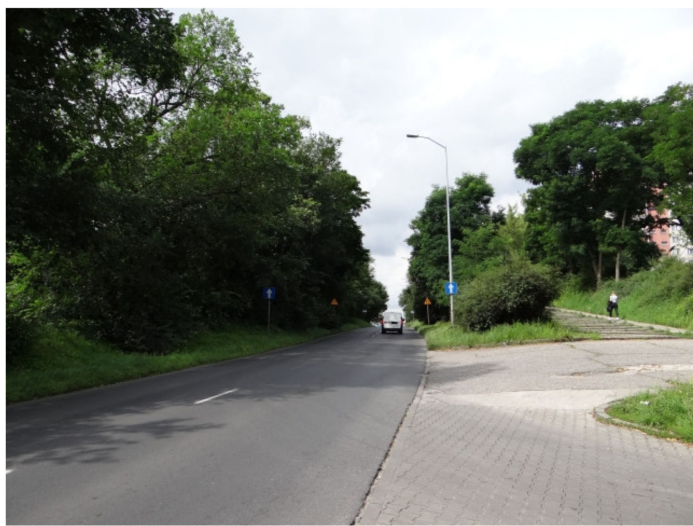

(a)

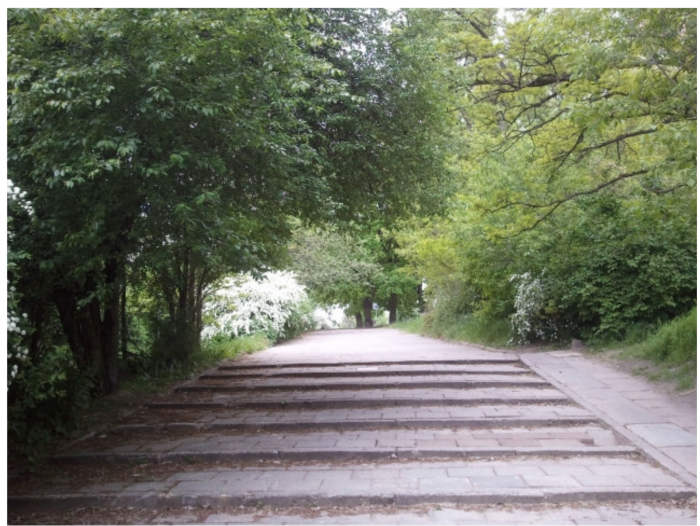

(b)

Figure 13. Layered vegetation on the approach to the analysed intersection along the westbound carriageway: (a) View of the approach to the intersection; (b) View of layered vegetation from both sides of the walkway running behind the slope of the road cut.

A different treatment was applied after the intersection, namely a wide dense hedge planted at the retaining wall constructed behind the bus stop area. This hedge and the row garages located behind the walkway in a 3.5-4 $\mathrm{m}$ deep depression (Figure 14) contributed to much lower noise levels recorded on the walkway surface, as compared to the walkway along the approach to the intersection, despite very similar speeds of traffic in these two locations (Figure 11).

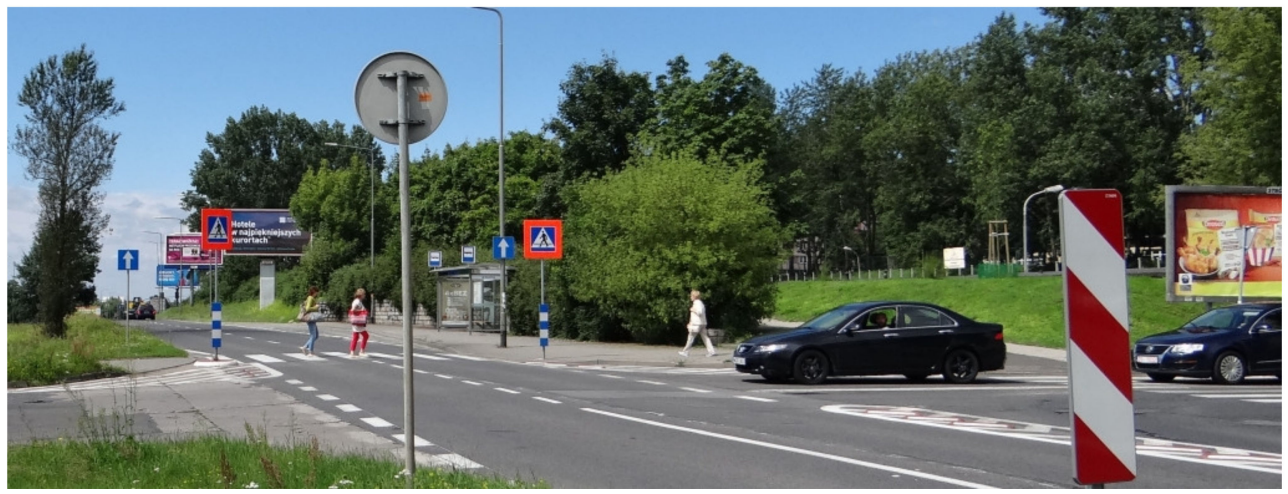

Figure 14. Retaining wall constructed behind the bust stop, terminated with a thick hedge composed of different species of different height and the walkway running between the hedge and the garages.

From the road noise distribution presented in Figure 12 it can be seen that the distribution is less varied after implementation of the lane narrowing treatment, as compared to the "before" situation presented in Figure 11. The noise levels of 64-66 dB(A) recorded on the walkway running behind the bust stop are much more favourable from the pedestrian's point of view, at lower average speeds on the test section No. C. In the case of the walkway running along the test section No. A, where the effect of the local estate road and grassed area including tall trees was taken into account in addition, no differences in the noise level 
were found by comparing the "before" and "after" situation. The sound wave propagates between the tree trunks reaching almost the area occupied by the high-rise buildings. Before the high-rise buildings there are hedges of different height accompanied by single shrubs, mitigating the effect of noise around the buildings. The only difference to the noise distribution before the implementation of the lane narrowing treatment (Figure 11) are smaller distances between the contour lines representing equal noise levels. It has to be noted that in both cases, the noise level right at the high-rise buildings located over $50 \mathrm{~m}$ away from the carriageway edge was lower than the maximum allowable noise level as per [47].

The analysis of noise distribution along the westbound carriageway demonstrated the significance of the local topography and roadside layered landscape. Varied vegetation, both in terms of height and location is highly relevant in this respect, mitigating the noise propagation.

Conversely, on the allotments side, the level of noise on the walkway running along the eastbound carriageway on the side facing the allotment gardens is about $66-68 \mathrm{~dB}$ over the whole length of the analysed street. Smaller noise levels were recorded only behind the hedge.

Summing up, in both cases the level of noise on the walkways ranged 66-68 dB(A) (Figures 11 and 12), i.e., slightly above the maximum allowable limit of $65 \mathrm{~dB}(\mathrm{~A})$ [47]. Noise levels recorded within the bus stops were $66-70 \mathrm{~dB}(\mathrm{~A})$, i.e., above that limit. Considering sporadic nature of pedestrian traffic in the analysed section and maximum 15 min waiting time at the bus stops, exposure to excessive noise levels should be considered short-term.

The above analyses confirm that the implemented lane narrowing had no significant effect on noise mitigation at the analysed intersection.

\section{Conclusions}

The findings of this study suggest that when planning lane narrowing on urban dual carriageways running through a built-up area an interdisciplinary approach should be applied to consider, besides the road conditions, also the local topography and roadside layered landscape. Otherwise, traffic calming treatments, while slowing down the traffic may worsen the acoustic environment in the surrounding area.

Lane narrowing on the urban dual carriageway is not an effective measure. The location of such narrowing should, in any case, consider the parameters that may have a determining effect on achieving the desired speed distribution, including the layout and profile of the existing road and location of intersections.

The presented noise data obtained from the measurements on narrowed lanes showed exceeding of the allowable noise level within the right-of-way and lack of mitigating effect of the implemented traffic calming measure, namely narrowing of the carriageway. The results show that roadside layered landscape has a strong bearing on the noise distribution. Planting of dense vegetation of varying height and spatial configuration and utilisation of natural local topography can effectively mitigate propagation of sound waves and absorb noise, thus improving the comfort of non-motorists.

Where the level of pedestrian traffic is high, the landscaping must be analysed as a crucial and indispensable part of the design process and selection of vegetation should consider not only the road conditions but also mitigation of the acoustic environment and separation of the noisy road from pedestrians. Thus, an interdisciplinary approach must be applied during design in order to improve not only road conditions but also the acoustic environment along urban roads. When slowing down the traffic is the only consideration, traffic calming treatments may actually worsen the acoustic environment in the surrounding area due to more braking and acceleration taking place as a result.

As a concluding statement to the above discussion on the effectiveness of lane narrowing on urban dual carriageways it is worth to note that no traffic accidents involving pedestrians have taken place on the analysed intersection since implementation of this treatment. 
Author Contributions: Conceptualization, A.B.S.; methodology, A.B.S.; formal analysis, A.B.S. and D.K.; data curation, D.K.; writing —original draft preparation, A.B.S.; writing-review and editing, A.B.S.; visualization, D.K.; supervision, A.B.S.; funding acquisition, D.K. All authors have read and agreed to the published version of the manuscript.

Funding: The research included in the paper were partly financed by grants of Faculty of Civil Engineering and Architecture, West Pomeranian University of Technology in Szczecin WBiA ZUT: DKD Dean's Decision No. 517-02-033-6728/17.

Institutional Review Board Statement: Not applicable.

Informed Consent Statement: Not applicable.

Data Availability Statement: Not applicable.

Conflicts of Interest: The authors declare no conflict of interest.

\section{References}

1. Road Safety TOOLKIT. Speed Management Techniques Aimed at Persuading Drivers to Adopt Safe Speeds Include Police Enforcement, Driver Education, Speed Limits and Engineering Treatments; Speed Menagement: London, UK, 2021. Available online: http: / / toolkit.irap.org/default.asp?page=treatment\&id=33 (accessed on 5 December 2020).

2. WHO. Speed Management-A Road Safety Manual for Decision-Makers and Practitioners; GRSP: Geneva, Switzerland, 2008. Available online: https:/ / www.who.int/roadsafety/projects/manuals/speed_manual/speedmanual.pdf (accessed on 5 December 2020).

3. SWOV Institute for Road Safety Research. Traffic Calming Schemes, Opportunities and Implementation Strategies; R-2003-22; van Schagen, I., Ed.; SWOV: Leidschendam, The Netherland, 2003. Available online: https://www.gtkp.com/assets/uploads/201001 10-011359-5067-R-2003-22.pdf (accessed on 5 December 2016).

4. Urban Traffic Areas, Booklet 3, Cross-Sectional Profiles; Road Directorate-Road Regulation Committee RD-RRC: København, Denmark, 2000.

5. Urban Traffic Areas-Part 7—Speed Reducers; Vejdirektoratet-Vejregeludvalget: København, Denmark, 1991.

6. Roads Development Guide; East Ayrshire Strathclyde Regional Council: Glasgow, UK, 1995. Available online: https:// www.ayrshireroadsalliance.org/Resources/pdf/Permit-application-forms/East-Ayrshire/RoadsDevelopmentGuideEAC.pdf (accessed on 17 May 2016).

7. Directives for the Design of Urban Roads. RASt 06; Working Group Highway Design, FGSV, Road and Transportation Research Association RTRA Germany Köln Edition: Köln, Germany, 2006.

8. Guidelines for Traffic Calming; Public Works City of Sparks, Traffic Division: Reno, NV, USA, 2007. Available online: https: / / cityofsparks.us/wp-content/uploads/2017/01/traffic-calming-guidelines.pdf (accessed on 17 May 2016).

9. Crevier, C. Les Aménagements en Modération de la Circulation, Étude et Applications; École De Technologie Supérieure Université Du Québec: Montreal, QC, Canada, 2007. Available online: http://www.bv.transports.gouv.qc.ca/mono/0967225.pdf (accessed on 7 December 2016).

10. Poe, C.M.; Mason, J.M. Analyzing Influence of Geometric Design on Operating Speeds Along Low-Speed Urban Streets: Mixed-Model Approach. Transp. Res. Rec. J. Transp. Res. Board 2000, 1, 18-25. [CrossRef]

11. Lamm, R.; Choueri, E.M.; Psarianos, B.P. A Practical Safety Approach to Highway Geometric Design, International Case Studies. In Proceedings of the International Symposium on Highway Geometric Design Practices, Boston, MA, USA, 30 August-1 September 1995.

12. Zhu, H.; Almukdad, A.; Iryo-Asano, M.; Alhajyaseen, W.K.M.; Hideki Nakamura, H.; Xin Zhang, X. A novel agent-based framework for evaluating pedestrian safety at unsignalized mid-block crossings. Accid. Anal. Prev. 2021, 159, 106288. [CrossRef] [PubMed]

13. Gonzalo-Ordena, H.; Pérez-Acebob, H.; Unamunzagaa, A.L.; Arcea, M.R. Effects of traffic calming measures in different urban areas. Transp. Res. Proc. 2018, 33, 83-90. [CrossRef]

14. Distefano, N.; Leonardi, S. Effects of Speed Table, Chicane and Road Narrowing on Vehicle Speeds in Urban Areas. In Proceedings of the VI International Symposium New Horizons 2017 of Transport and Communications, Sarajevo/Bosnia, Herzegovina, 17-18 November 2018. Available online: https:/ / www.researchgate.net/publication/328738163_EFFECTS_OF_SPEED_TABLE_ CHICANE_AND_ROAD_NARROWING_ON_VEHICLE_SPEEDS_IN_URBAN_AREAS (accessed on 17 May 2020).

15. Loprencipe, G.; Moretti, L.; Pantuso, A.; Banfi, E. Raised Pedestrian Crossings: Analysis of Their Characteristics on a Road Network and Geometric Sizing Proposal. Appl. Sci. 2019, 9, 2844. [CrossRef]

16. Akgol, K.; Gunay, B.; Aydin, M.M. Geometric optimisation of chicanes using driving simulator trajectory data. Proc. Inst. Civ. Eng. Transp. 2019, 1900019, 1-11. [CrossRef]

17. Mok, J.H.; Landphair, H.C.; Naderi, J.R. Landscape Improvement Impacts on Roadside Safety in Texas. Landsc. Urban Plan. 2006, 78, 263-274. [CrossRef]

18. Paige, M. Speed and Road Traffic Noise. The Role that Lower Speeds Could Play in Cutting Noise from Traffic; Report; UK Noise Association: London, UK, 2009. 
19. European Environment Agency. Environmental Noise in Europe-2020; Publications Office of the European Union: Luxembourg, 2020.

20. Blue Book Road Infrastructure, Jaspers. In Niebieska Książa. Sektor Transportu Publicznego w Miastach, Aglomeracjach i Regionach; 2015. Available online: https:/ / www.cupt.gov.pl/ (accessed on 30 November 2020).

21. ISO. Sustainable Development in Communities_Management System for Sustainable Development_Requirements with Guidance for Use; International Organization for Standardization: Geneva, Switzerland, 2016.

22. Jaskuła, P.; Ejsmont, J.; Stienss, M.; Ronowski, G.; Szydłowski, C.; Świeczko-Żurek, B.; Ryś, D. Initial Field Validation of Poroelastic Pavement Made with Crumb Rubber, Mineral Aggregate and Highly Polymer-Modified Bitumen. Materials 2020, $13,1339$. [CrossRef]

23. Gardziejczyk, W.; Jaskuła, P.; Ejsmont, J.; Motylewicz, M.; Stienss, M.; Mioduszewski, P.; Gierasimiuk, P.; Zawadzki, M. Investigation of Sound Properties of Poroelastic Asphalt Mixtures in Laboratory and Field Conditions. Materials 2021, 14, 2649. [CrossRef]

24. Gardziejczyk, W.; Motylewicz, M. Przebudowa dróg i ulic a klimat akustyczny w ich otoczeniu. Mater. Bud. 2015, 7, 99-101. [CrossRef]

25. Xiong, Y.; Tuononen, A. A laser-based sensor system for tire tread deformation measurement. IOP Publ. Meas. Sci. Technol. 2014, 25, 115103. [CrossRef]

26. Heutschi, K.; Favre A-Ch Thomann, G.; Wunderli, J.-M.; Schrade, A.; Brink, M. Tempo 30 als Lärmschutzmassnahme: Grundlagenpapier zu Recht-Akustik—Wirkung, Eidgenössische Kommission für Lärmbekämpfung; EKLB: Bern, Switzerland, 2015.

27. World Health Organization. Burden of Disease from Environmental Noise-Quantification of Healthy Life Years Lost in Europe; WHO Regional Office for Europe: Copenhagen, Denmark, 2011. Available online: https://apps.who.int/iris/handle/10665/326424 (accessed on 29 August 2020).

28. Dickens, R.; Angulo, M.; Turner, S.; Gill, J.; Abdul, M.; Hirani, H. Environmental Noise: Valuing Impacts on: Sleep Disturbance, Annoyance, Hypertension, Productivity and Quiet; Report; Interdepartmental Group on Costs and Benefits Noise Subject Group, Department for Enviroment Foof \& Rural Affairs: London, UK, 2014.

29. Engel, Z. Ochrona Środowiska przed Drganiami i Hałasem; PWN: Warszawa, Poland, 2001.

30. Klasy Pochłaniania Dźwięku. Available online: https://www.ecophon.com/pl/about-ecophon/acoustic-knowledge/how-tocreate-good-room-acoustics/sound-absorption-classes/ (accessed on 8 September 2020).

31. Sadowski, J.; Szudrowicz, B. The Influence of Materials and Construction on the Sound Climate in Dwellings and Its Effect on Residents' Health. Final report (Project No 05-202-2, cooperation PI-USA); Building Research Institute: Warsaw, Poland, 1975.

32. Sadowski, J. Akustyka w Urbanistyce Architekturze i Budownictwie; Arkady: Warszawa, Poland, 1971.

33. Wilkosz-Mamcarczyk, M. Rola zieleni w procesach rewitalizacji miast (w kontekście zrównoważonego rozwoju). Ph.D. Thesis, Politechnika Krakowska, Kraków, Poland, 2015. Available online: https://repozytorium.biblos.pk.edu.pl/redo/resources/2623 6/file/suwFiles/WilkoszMamcarczykM_RolaZieleni.pdf (accessed on 10 September 2021).

34. Dzhambov, A.M.; Dimitrova, D.D. Urban green spaces' effectiveness as a psychological buffer for the negative health impact of noise pollution: A systematic review. Noise Health 2014, 16, 157-165. [CrossRef]

35. Uebel, K.; Marselle, M.; Dean, A.J.; Rhodes, J.R.; Bonn, A. Urban green space soundscapes and their perceived restorativeness. People Nat. 2021, 3, 756-769. [CrossRef]

36. Franěk, M.; Režný, L.; Šefara, D.; Cabal, J. Effect of birdsongs and traffic noise on pedestrian walking speed during different seasons. PeerJ 2019, 7, e7711. [CrossRef]

37. Hedblom, M.; Knez, I.; OdeSang, Å.; Gunnarsson, B. Evaluation of natural sounds in urban greenery: Potential impact for urban nature preservation. R. Soc. Open Sci. 2017, 4, 170037. [CrossRef]

38. Abbott, P.; Tyler, J.; Layfield, R. Traffic Calming: Vehicle Noise Emissions Alongside Speed Control Cushions and Road Humps, Raport 180; Transport Research Laboratory TRL: Berkshire, UK, 1995.

39. Bachok, K.S.R.; Hamsa, A.A.K.; bin Mohamed, M.Z.; Ibrahim, M. A theoretical overview of road hump effects on traffic noise in improving residential well-being. Transp. Res. Proc. 2017, 25, 3383-3397. [CrossRef]

40. Džambas, T.; Dragčević, V.; Lakušić, J. Impact of vertical traffic calming devices on environmental noise. Građevinar 2020, 12, 1131-1143. [CrossRef]

41. Ellebjerg, L. Noise Control through Traffic Flow Measures-Effects and Benefits Report 151; Danish Road Institute-Electronic: Hedehusene, Denmark, 2007.

42. Gozalo, G.R.; Suárez, E.; Montenegro, A.L.; Arenas, J.P.; Juan Miguel Barrigón Morillas, J.M.B.; González, D.M. Noise Estimation Using Road and Urban Features. Sustainability 2020, 12, 9217. [CrossRef]

43. Wilson, K.; Pettit, C.H.L.; Ostashew, V.E. Sound propagation in the atmospheric boundary layer, Sounds Today. Spring 2015, 11, 44-53.

44. Google Earth. Available online: http:/ / www.earth.google.com (accessed on 12 September 2020).

45. ISO. Description, Measurement and Assessment of Environmental Noise, Part 2: Determination of Environmental Noise Levels; International Organization for Standardization: Geneva, Switzerland, 2017.

46. Solomon, D. Accidents on Main Rural Highways Related to Speed, Drivers and Vehicle; Bureau of Public Roads: Washington, DC, USA, 1964 
47. World Health Organization. Environmental Noise Guidelines for the European Region; World Health Organization-Regional Office for Europe: Copenhagen, Denmark, 2018. Available online: https://www.euro.who.int/en/publications/abstracts/ environmental-noise-guidelines-for-the-european-region-2018 (accessed on 14 September 2020).

48. Van den Berghe, W. Road safety Thematic Report_Speeding; European Road Safety Observatory, European Commission, Directorate General for Transport: Brussels, Belgium, 2020. Available online: https://ec.europa.eu/transport/road_safety/sites/default/ files/pdf/2020-10-08-road_safety_thematic_report_speed.pdf (accessed on 20 August 2021).

49. Martin, J.L.; Wu, D. Pedestrian fatality and impact speed squared: Cloglog modeling from French national data. Traffic Inj. Prev. 2018, 19, 94-101. [CrossRef]

50. Heutschi, K.; Favre A-Ch Thomann, G.; Wunderli, J.M.; Schrade, A.; Brink, M. La Limitation à 30 km/h Comme Mesure de Protection Contre le Bruit; Commission Fédérale pour la Lutte Contre le Bruit CFLB: Berne, Switzerland, 2015.

51. Abhijith, K.V.; Kumar, P.; Gallagher, J.; McNabola, A.; Baldauf, R.; Pilla, F.; Broderick, B.; Di Sabatino, S.; Pulvirenti, B. Air pollution abatement performances of green infrastructure in open road and built-up street canyon environments-A review. Atmos. Environ. 2017, 162, 71-86. [CrossRef]

52. Suchocka, M. Drzewo jako element zielonej infrastruktury. Probl. Ekol. Kraj. 2013, T.XXXVI, 85-94.

53. Budziński, B.; Sołowczuk, A. Wpływ zagospodarowania terenu na klimat akustyczny na terenie MOP. Przeglad Komun. 2015, LXX, 6-10. Available online: http://www.przeglad.komunikacyjny.pwr.wroc.pl/06_2015/PK_06_15.pdf (accessed on 20 October 2015).

54. Al-Dabbous, A.N.; Kumar, P. The influence of roadside vegetation barriers on airborne nanoparticles and pedestrians exposure under varying wind conditions. Atmos. Environ. 2014, 90, 113-124. [CrossRef]

55. Brantley, H.L.; Hagler, G.S.W.; Deshmukh, P.J.; Baldauf, R.W. Field assessment of the effects of roadside vegetation on near-road black carbon and particulate matter. Sci. Total Environ. 2014, 468-469, 120-129. [CrossRef]

56. Gromke, C.; Jamarkattel, N.; Ruck, B. Influence of roadside hedgerows on air quality in urban street canyons. Atmos. Environ. 2016, 139, 75-86. [CrossRef] 